\title{
ISLAM DAN SEJARAHNYA PADA MASYARAKAT JAMBI SEBERANG
}

\author{
Apdelmi \\ Fakultas Ilmu Budaya Universitas Jambi \\ Jl. Lintas Jambi - Muara Bulian Km. 15, Kota Jambi \\ apdelmi1985@gmail.com
}

\begin{abstract}
Islam and Its History of The Jambi Community. The existence of Islam in Jambi due to the arrival of ships from the Turkish Sultanate for spreading of Islam in Jambi, the group was led by Ahmad Ilyas or Ahmad Barus. They came here because the ship of his entourage was stranded at Pulo Berhalo because Ahmad Ilyas spread Islam in Jambi besides that he destroyed the idols at the idol island so Ahmad Ilyas was nicknamed Datuk Paduko Berhalo. It was known that the entry of Islam in the Jambi Seberang community was heavily influenced by Islamic traders who entered and sailed along the Batanghari river. The discovering of several relics from Arab, Persian and Turkish traders became one of the proofs that the process of spreading Islam had ever taken place. More than that the Malay Arabian Culture is very strongly attached to the people of Jambi Seberang. Even attached to the customs of the Jambi Malays that we know as "Bersendi Syarak Traditional, Syarak Bersendi Kitabullah"
\end{abstract}

Keywords: Islamic History, Jambi Seberang, Batanghari River.

Abstrak: Islam dan Sejarahnya pada Masyarakat Jambi Seberang. Adanya Islam di Jambi karena kedatangan kapal dari Kesultanan Turki untuk penyebaran agama Islam di Jambi, rombongan tersebut di pimpin oleh Ahmad Ilyas atauAhmad Barus. Mereka datang kemari karena kapal rombongannya terdampar di Pulo Berhalo kaerna Ahmad Ilyas menyebarkan agama Islam di Jambi selain itu beliau yang menghancurkan patung-patung berhala sembahan di pulau berhala sehingga Ahmad Ilyas dijulukisebagai Datuk Paduko Berhalo. Diketahui bahwa masuknya Islam pada masyarakat Jambi Seberang banyak dipengaruhi oleh pedagang-pedagang Islam yang masuk dan berlayar di sepanjang sungai Batanghari. Ditemukannya beberapa peninggalan dari pedagang-pedangang Arab, Persia dan Turki menjadi salah satu bukti bahwa proses penyebaran Islam tersebut pernah terjadi. Ditambah lagi bahwa Budaya Arab Melayu sangat melekat kuat pada masyarakat Jambi Seberang. Bahkan melekat pada adat orang Melayu Jambi yang kita kenal dengan "Adat Bersendi Syarak, Syarak Bersendi Kitabullah"

Kata Kunci: Sejarah Islam, Jambi Seberang, Sungai Batanghari.

\section{Pendahuluan}

Secara geografis Provinsi Jambi terletak pada $0 \circ 45^{\prime}-2 \circ 45^{\prime}$ Lintang Selatan dan 101'10'-104'55' Bujur Timur di bagian tengah Pulau Sumatera, sebelah Utara berbatasan dengan Provinsi Riau, Sebelah Timur dengan Laut Cina Selatan Provinsi Kepulauan Riau, sebelah Selatan berbatasan dengan Provinsi Sumatera
Selatan dan sebelah Barat berbatasan dengan Provinsi Sumatera Barat. Posisi Provinsi Jambi cukup strategis karena langsung berhadapan dengan kawasan pertumbuhan ekonomi yaitu IMS-GT (Indonesia, Malaysia, Singapura Growth Triangle). Luas wilayah Provinsi Jambi sesuai dengan Undang-undang Nomor 19 tahun 1957, tentang Pembentukan Daerah- 
Daerah Swatantra Tingkat I Sumatera Barat, Jambi dan Riau, yang kemudian ditetapkan menjadi Undang-Undang Nomor 61 tahun 1958 (Lembaran Negara Tahun 1958 Nomor 112) adalah seluas $53.435,72 \mathrm{~km}^{2}$ dengan luas daratan $50.160,05 \mathrm{~km}^{2}$ dan luas perairan 3.274,95 $\mathrm{Km}^{2}$

Provinsi Jambi memiliki luas wilayah 50.058,16 $\mathrm{km}^{2}$ dengan jumlah penduduk 3.406.178 jiwa, memiliki banyak suku yang mendiaminya, di antaranya adalah suku Kerinci, suku Kubu, suku Batin, suku Melayu, dan beberapa suku minoritas lainnya. Suku-suku tersebut menyebar di 9 kabupaten, 2 kota, 138 kecamatan, 163 kelurahan, dan 1.398 desa, yang umumnya mendiami di wilayah pinggiran sungai Batang Hari sebagai pusat perekonomian dari masa lalu hingga masa sekarang (menurut sumber Permendagri Nomor 39 Tahun 2015).

Wilayah Jambi berada pada cekungan sungai yang memiliki banyak anak sungai, Batang Hari merupakan sungai terpanjang di Sumatra, yang memiliki mata air di Bukit Barisan dan berkelok-kelok sepanjang 800 kilometer. Sungai Batanghari menjadi tulang punggung bagi masyarakat yang tinggal pada kawasan pinggiran sungai. Anak sungai Batanghari antara lain Sungai Tembesi, Sungai Merangin, Sungai Asai, Sungai Tabir, Sungai Bungo, Sungai Tebo dan Sungai Jujuhan.Tidak kalah penting fungsinya dari anak sungai yang telah disebutkan, terdapat cekungan tangkapan air sendiri di Tungkal yang berbatasan dengan Indragiri.Sungai sungai tersebut merupakan urat nadi yang menghubungkan antar wilayah dan dusun- dusun. Letak ibu kota Kesultanan yang bernama Jambi tidak jauh dari tepi sungai dan kawasan ini berada 90 kilometer dari muara sungai Batang Hari. Posisi Jambi yang terletak tidak jauh dari garis Khatulistiwa, menciptakan pemisah yang cukup jelas antara musim Timur dan musim Barat27

Daerah Sungai Batanghari memiliki sejarah yang cukup panjang. Sebelum abad ke 19 M, sungai menjadi sarana transportasi yang penting dari dan ke daerah pedalaman. Pengangkutan barang dan manusia dilakukan melalui jalur sungai, hal ini terbukti dari beberapa situs arkeologi yang menunjukkan adanya pemusatan pemukiman kuno di beberapa tempat di pinggir sungai Batanghari (Aulia T, 2016)

Keberadaan sungai Batanghari yang memiliki fungsi yang sangat penting bagi penyaluran komoditas lokal dan juga sebagai jalur transportasi yang menghubungkan setiap wilayah yang ada di Jambi.Sehingga hubungan antara wilayah pedalaman dan pesisir dapat terlihat melalui perdagangan yang terjadi di sepanjang kawasan sungai Batanghari.

Sungai Batanghari merupakan jalur pelayaran dan perdagangan yang strategis pada masa lampau apalagi pada masa jayanya kerajaan Sriwijaya. Sungai Bataghari merupakan transportasi yang sangat dihandalkan untuk melakukan pelayaran serta perdagangan baik secara nasional maupun secara internasional pada kala itu. Tidak hanya bidang ekonomi, sosial, budaya, bahkan agama. Sungai Batanghari memiliki manfaat besar bagi masyarakat di sekitar sungai Batanghari, ini merupakan beberapa yang menenjadi bukti peradaban masyarakat Jambi. Sungai Batanghari merupakan 


\section{Apdelmi \\ Islam dan Sejarahnya pada Masyarakat Jambi Seberang}

sumber penghidupan yang sangat berperan sekalai bagi masyarakatnya yang tinggal disepanjang daerah aliran sungai tersebut.

Sungai Batanghari bermuara di Tanjung Jabung Timur dan langsung bertemu dengan Selat Malaka, Selat Berhala, Selat Kalimata dan Laut Natuna. Ini merupakan jalur pelayaran yang sangat berperan penting pada masa awal masuknya agama Islam di Jambi, karena menghubungkan semua pelayaran dan perdagangan yang ada di Asia. Pada masa itu juga merupakan pusat pelayaran dan perdagangan internasional yang sangat besar dan berperan penting dalam menghubungkan Asia Timur- Asia Tenggara-Asia Barat yang berpusat di Selat Malaka. (Gambar 1)

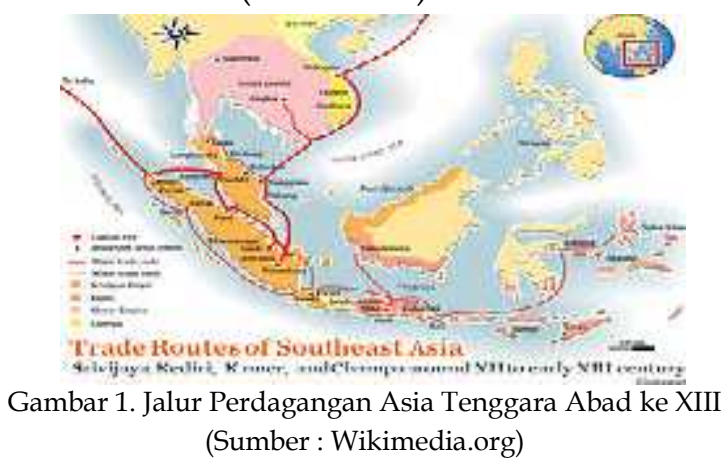

Jambi merupakan wilayah yang terkenal dalam literatur kuno, namun tidak banyak yang mengetahui mengenai peran sungai Batanghari dalam penyebaran agama Islam. Nama negeri ini sering disebut-sebut dalam prasastiprasasti dan juga berita-berita Tiongkok. Selain itu Jambi merupakan bagian penting dalam penyebaran agama Islam. Adanya Islam di Jambi karena kedatangan kapal dari kesultanan Turki untuk penyebaran agama Islam di jambi, rombongan tersebut di pimpin oleh Ahmad Ilyas atau Ahmad Barus. Mereka datang ke Jambi karena kapal rombongannya terdampar di Pulo Berhalo. Ahmad Ilyas menghancurkan patung-patung berhala sembahan di pulau berhala sehingga Ahmad Ilyas dijulukisebagai Datuk Paduko Berhalo.

Keberhasilan DatukPaduko Berhalo dan anak-anaknya dalam mengislamisasikan masyarakat Jambibukanberarti menyebabkan masyarakat Jambi menjalankan kehidupan Islam sepenuhnya. Namun dalam proses penerapannya masih belum sesuai dengan ajaran Islam dikarenakan mereka belum dapat membedakan mana yang halal dan mana yang haram, sebab pada masa itu mereka masih dalam proses transisi dari ajaran Hindu Budha. Setelah Datuk Paduko Berhalo, munculnya tokoh Datuk Sintai sebagai penyebar agama Islam di Jambi meneruskan proses islamisasi. Datuk sintai memiliki seorang putri bernama Nyai Resik, beliau merupakan keturunan China. Selang waktu berlalu karena Jambi merupakan jalur perdagangan, singgahlah seorang kebangsaan Arab bernama Al-Habbib Husin Al Baraqbah Bin Ahmad Baraqbah, beliau datang bukan hanya sebagai seorang pedagang melainkan juga menyebarkan ajaran Islam.

Al-Habib Husin Al Baraqbah menikahi Nyai Resik untuk mempermudah proses islamisasi di Jambi yang pada saat itu memang masyarakat Jambi telah memeluk agama Islam tapi kehidupannya belum terlepas dalam ajaran Hindu Budha, disinilah misi AlHabib Husin Al Baraqbah untuk menyempurnakan ajaran Islam yang ada di Jambi, setelah 20 tahun menetap di Jambi Al-Habib Husin Al Baraqbah 
memiliki banyak anak, kemudian anak ke3 beliau yang bernama Khosyim Bin Husein dialah yang meneruskan perjuangan ayahnya dalam menyempurnakan ajaran Islam yang berada di Jambi.

Berbagai kisah dan Teori mengenai masuknya Islam di Jambi mendorong penulis untuk mengkaji melalui studi pustaka, mengenai Islam dan Sejarahnya pada masyarakat Jambi, terutama masyarakat Jambi Seberang yang tinggal di daerah aliran sungai Batanghari, sekaligus tempat ditemukannya peninggalan-peninggalan bersejarah dari para pedagang Islam Nusantara yang pernah berlayar dan berdagang yang melalui sungai Batanghari.

\section{A. Pembahasan}

Diskusi dan perdebatan mengenai sejarah masuknya Islam masih terus menjadi topik hangat yang sering diperbincangkan. Meskipun Islam telah masuk ke Indonesia telah berabad-abad lamanya. Para ahli terus saja membahas berbagai topik mengenai tempat kedatangan Islam, para pembawanya, dan waktu kedatangannya.Nusantara memang merupakan sebuah wilayah yang ramai dilalui oleh para pedagang asing dari berbagai wilayah di belahan dunia, orangorang Cina dari bagian utara, orang-orang India dan Arab dari belahan barat dan beberapa pedagang asing yang datang dari bangsa yang kurang dikenal.

Sejarah Nusantara merupakan peristiwa yang panjang dan selalu dikaitkan dengan perdagangan. Menurut Anthony Reid, perdagangan merupakan hal yang vital bagi Asia Tenggara dimana di dalamnya termasuk Nusantara. Hal ini dilihat dari peran laut yang menjadi satusatunya jalur atau lalu lintas yang bisa dilalui sebagai penghubung antar negara maritim. Posisi Nusantara yang strategis menjadikan daerah-daerah di sekitarnya sebagai tempat perniagaan yang selalu ramai didatangi oleh para pedagang asing. Jalur maritim antara Cina dan pusat-pusat pemukiman penduduk seperti India, Timur-Tengah dan Eropa mempengaruhi meningkatnya perdagangan maritim Internasional. Produk yang menjadi andalan di Asia Tenggara berupa cengkeh, pala, kayu cendana, kayu sapan, kamper dan pernis mendapatkan pasaran tinggi sejak zaman Romawi dan Dinasti Han, Cina.

Kajian tentang asal-usul, waktu kedatangan, dan penyebaran Islam pada masa awal di Nusantaradan Kawasan AsiaTenggara secara keseluruhan merupakan enduring issues yang terus berlanjut sampai sekarang. Tidak adanya catatan tertulis yang valid mengenai kisah-kisah konversi penduduk lokal ke dalam Islam telah menimbulkan berbagai teori dan spekulasi mengenai sejarah awal penyebaran dan perkembangan Islam di suatu wilayah di Nusantara. ${ }^{1}$ Sebagai pendukung informasi sejarah, digunakan beberapa sumber-sumberlokal (historiografi tradisional) yang dimiliki oleh masyarakat setempat. Memang harus diakui, kisah-kisah yang terdapat dalam sumber-sumber lokal sering kali memuat unsur-unsur legenda danmitos. Akan tetapi, Vansina justru menekankan pentingnya historiografi tradisional sebagai salah satu sumber sejarah suatu wilayahdan masyarakat. Sumber-sumber lokal merupakan media untukmerekam sejarah suatu masyarakat dan menjadi 
tradisi resmi yang disampaikan secara turun-temurun. $^{2}$

Keadaan Nusantara yang selalu ramai oleh para pedagang asing mengakibatkan adanya pertemuan budaya, oleh sebab itu tidak heran jika didalam kehidupan masyarakat Nusantara ditemukan persamaan budaya dengan daerah lain di luar Nusantara. Fenomena persamaan unsur kebudayaan yang terjadi di Nusantara menimbulkan perdebatan panjang oleh para ahli sejarah mengenai tempat kedatangan Islam. Beberapa ahli sejarah mengatakan bahwa Islam dibawa langsung dari Arab oleh para pedagang dan musafir Arab,2sedangkan sejarawan yang mendasarkan pada pengamatan unsurunsur budaya dan Mazhab Syafi'i lebih dominan ke India.3 Teori yang tidak kalah populer dalam islamisasi Nusantara adalah teori Persia. Tidak jauh dari persamaan kebudayaan, teori ini juga melihat adanya persamaan antara budaya Syi'ah di Persia dengan budaya di Nusantara. ${ }^{4}$

Kisah dan catatan yang terdapat dalam sumber-sumber lokal banyak pula yang memiliki keselarasan dan melengkapi argumen-argumen yang lebih ilmiah dari para sarjana. Dari sejumlah informasi yang terdapat dalam historiografi tradisional adalah mengenai sejarah dan kisah-kisah pengislaman beberapa penguasa dan penduduk lokal di Kawasan Melayu-Nusantara. Kisahnya sering kali diwarnai dengan cerita tentang kedatangan orang orang asing, yang umumnya diasosiasikan berasal dari Timur Tengah, khususnya penyiar Islam dari Arab dan Persia. Munculnya kisah beberapa Muslim dari Arab dan Persia dalam historiografi lokal (babad,tambo, hikayat, tarsilah, dan sajarah) adalah dampak dari meningkatnyahubungan politik dan agama antara beberapa kesultanan di Nusantaradan Timur Tengah. ${ }^{3}$

Jika dalam abad-abad sebelumnya, ${ }^{4}$ kedatangan Muslim Arab dan Persia ke Nusantara lebih kepada urusan ekonomi perdagangan, memasuki abad ke-13, mereka juga secara khusus memberikan perhatian pada usaha-usaha untuk menyebarkan Islam kepada penduduk lokal.Tentang peranan orang-orang dari negeri Arab sebagai penyiarIslam dan pernanan politik mereka di Nusantara adalah sangat lazim didengar. Di dalam Hikayat Raja-raja Pasai, misalnya, (ditulis sekitar1350) menceritakan tentang kedatangan seorang Muslim dari Arab bernama Syaikh Ismail. Ia berhasil mengislamkan Merah Silu, penguasalokal di Pasai, dan tampil sebagai penguasa pertama Kesultanan IslamSamudra Pasai, dengan memperoleh gelar menjadi Sultan Malik al-Shalih(w.698/1297). ${ }^{5}$

Beberapa ahli sejarah mengatakan bahwa Islam dibawa langsung dari Arab oleh para pedagang dan musafir Arab,sedangkan sejarawan yang mendasarkan pada pengamatan unsurunsur budaya dan Mazhab Syafi'i lebih dominan ke India.Teori yang tidak kalah populer dalam islamisasi Nusantara adalah teori Persia. Tidak jauh dari persamaan kebudayaan, teori ini juga melihat adanya persamaan antara budaya Syi'ah di Persia dengan budaya di Nusantara.

Hikayat Raja-raja Aceh juga menceritakan asal-usulkesultanan Aceh yang diyakini berasal dari keturunan 
Arab, melalui Syaikh Jamal al-'Alam, yang dikirim oleh Sultan Ustmani dari Turki.6Sejarah Melayu (ditulis 1500-an) mengisahkan pengislaman penguasa Malaka, Parameswara, oleh Sayyid 'Abd al-'Aziz yang juga datang dariArab. Parameswara kemudian diberi nama Sultan Muhammad Syah. ${ }^{7}$

Kekaguman dan penghormatan terhadap orang-orang keturunan Arab yang sangat menyebarkan Islam sangat dihargai dan dikagumi di dalam historiografi tradisional. Kisah kedatangan seorang Muslim baik itu dari Arab, Persia,atau mimpi (ru'yah) bertemu Nabi telah menjadi salah satu tipikalpenting dalam sejarah Islam di Nusantara. Akan tetapi, historiografilokal dari Jambi justru mengisahkan tentang peran seorang Muslim dariTurki dalam sejarah awal Islam di Jambi. Menurut naskah-naskah lokal dan sejarah lisan masyarakat Jambi, kisah tentang orang Turki tersebut tidak hanya menyeritakan tentang peranannya dalam menyebarkan Islam tetapi juga menjadi cikal-bakal berdirinya kesultanan Jambi dan menjadi silsilah keturunan rajaraja Jambi. Kisah orang Turki dalam sejarah Jambi tercatat pada akhir abad ke19 sampai awal abad ke-20.

Islam telah berkembang seiring dengan tumbuh dan berkembangnya pendidikan agama islam. Pertumbuhan ajaran Islam ini diawali dengan system keyakinan dengan pengesaan Tuhan kemudian berkembang menjadi ajaran yang kompleks yang mengatur setiap aspek kehidupan yang meliputi aspek ekonomi, sosial, politik dan budaya. Islam juga telah menjadi peradaban global. Tidak hanya menjadi agama orang Arab tetapi juga menjadi agama setiap suku bangsa yang ada di dunia. Islam juga telah mempengaruhi agama orang Melayu, termasuk didalamnya Melayu Jambi. Sehingga sulit untuk dipisahkan antara Islam dan Melayu. Dalam adat Melayu diungkapkan dasar islam yang berbunyi "Adat Bersandi Sarak, Sarak Bersandi Kitabullah

Daerah aliran sungai Batang hari merupakan jalur transportasi pertama yang dikenal oleh pedagang asing di kota Jambi. Sejak abad ke-7 M daerah aliran sungai Batanghari Jambi dilewati oleh pedagang dari Tiongkok menuju ke India dan Arab. Kota Jambi menjadi daerah penting sebelum munculnya pelabuhan kota Malaka sekitar abad ke-15 M. 8 Semakin terkenalnya Malaka sebagai pelabuhan dagang mengakibatkan berkurangnya para pedagang asing yang lewat di pantai Timur Sumatra. Beralihnya jalur perdagangan tersebut tidak seutuhnya menghilangkan eksistensi Jambi sebagai kota pelabuhan dagang. Kekayaan hasil alam berupa lada, pinang dan lain-lainnya tetap menjadi komoditi utama di Jambi, sehingga masyarakat Jambi pun mengambil andil dalam perniagaan dunia pada abad ke-15.

Ditemukannya pecahan kaca berwarna gelap dan hijau muda di daerah Muara sabak menyatakan adany ainteraksi pedagang asing dengan masyarakat Jambi. Selain itu ditemukan pula pecahan kaca berwarna biru tua, biru muda, hijau, kuning, dan merah di Muara Jambi. Selain itu ditemukan pula sejumlah permata yang diperkirakan berasal dari Arab dan Persia (Iran) sekitar abad ke-9 hingga abad ke-13 M bukti ini juga diperkuat dari berita cina dalam kitab Peihu-lu tahun $875 \mathrm{M}$, menyebutkan sebuah 


\section{Apdelmi \\ Islam dan Sejarahnya pada Masyarakat Jambi Seberang}

nama Chan-Pei yang didatangi oleh pedagang Po'se (Persia) untuk mengumpulkan barang-barang dagangan berupa buah pinang (Areca nuts) ${ }^{9}$. Elsbet Locher seorang peneliti dari Belanda mengatakan proses islamisasi di Jambi dilakukan oleh orang kebangsaan Turki pada abad ke-15 M. ${ }^{10}$ Bukti yang dibawanya berupa folklore atau ceritarakyat yang berkembang hingga saat ini. Minimnya sumber sejarah berupa benda-benda peninggalan sejarah Islam di Jambi abad ke-15 M membuat Elsbert tidak menulis banyak mengenai kerajaan Islam di Jambi.

Bukti otentik yang dianggap benar mengenai proses islamisasi di Jambi yang dilakukan oleh orang turki adalah ditemukannya makam Ahmad Barus atau yang lebih dikenal dengan Paduka Datuk Berhalo di pulau Berhala (Gambar 2) yang saat ini menjadi wilayah bagian dari provinsi kepulauan riau. ${ }^{11}$ Berdirinya lembaga pendidikan Islam di Seberang Kota Jambi dan sekaligus ditemukannya pesantren-pesantren tertua menjadikan Kota Jambi Seberang representasi perkembangan pendidikan agama Islam di Jambi.

Diungkapkan oleh R. Abdullah (sejarawan Jambi), hasil perkawinan antara Orang Kayo Hitam dan Putri Mayang Mangurai merupakan leluhur orang Jambi. ${ }^{12}$ Orang kayo Hitam adalah penyebar agama Islam di Jambi pada abad ke 15. Ia putra Datuk Paduka Berhala dari perkawinannya dengan Putri Selaras Pinang Masak. Orang Kayo Hitam adalah pendiri kerajaan Melayu Islam di Jambi. Raja-raja dari Kesultanan Jambi adalah keturunan "Orang Kayo Hitam". Ia memiliki tiga orang saudara, seorang putri benama Orang Kayo Gernuk dan dua orang laki-laki orang Kayo Pingai dan Orang Kayo Padataran. ${ }^{13}$ Pada masanya pusat kerajaan Islam dipindahkan dari Pulau Berhala, (sekarang di Provinsi Kepulauan Riau yang sebelumnya berada di Kabupaten Tanjung Jabung Timur, Provinsi Jambi), ke daerah yang bernama "Tanah Pilih". Berpindahnya pusat kerajaan dari daerah pantai ini, telah mengubah kehidupan maritim menjadi pola agraris. Daerah Pantai yang diajadikan sebagai tempat pertemuan para pedagang tersebut menyebabkan kemungkinan masuknya unsur-unsur kebudayaan lain di Jambi cukup tinggi, seperti unsur agama Islam yang dibawa oleh para pedagang Arab dan Gujarat.

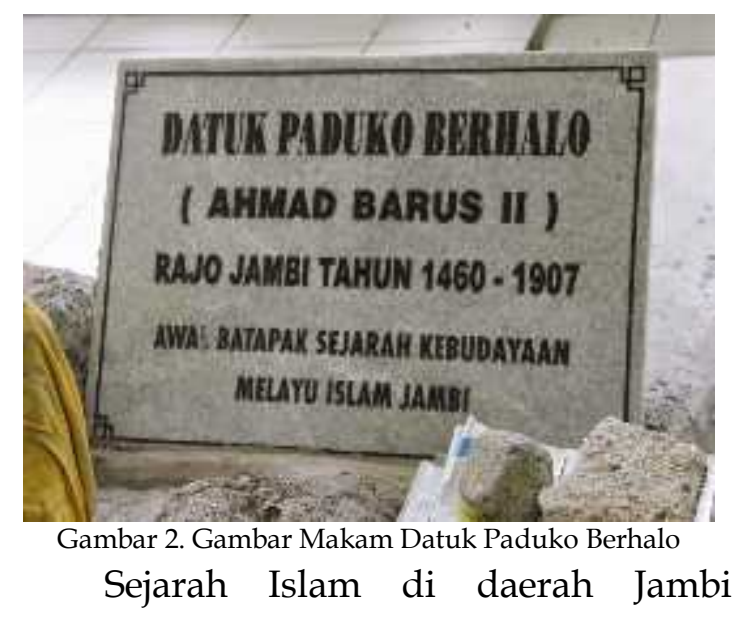

Seberang erat kaitannya dengan sejarah masuknya Islam di daerah Jambi. Di kalangan masyarakat, berkembang suatu pendapat bahwa agama Islam telah ada di daerah ini pada tahun 1460 Masehi, atau sekitar abad ke 15 Masehi. Pembawanya adalah seorang saudagar Arab yang bernama Ahmad Salim, yang kemudian terkenal dengan sebutan "Datuk Paduka Berhala". Ia kawin dengan seorang raja Jambi yang bemama "Putri Selaras Pinang Masak". Melalui perkawinan ini pengaruh Islam telah masuk ke dalam Keraton 
(kekuasaan atau politik), dan baru pada tahun 1615 Masehi pengaruh Islam betulbetul nampak. Islam telah menggeser sistem kerajaan dengan "sistem kesultanan Jambi", yaitu dengan dinobatkannya Pangeran Kedah yang bergelar Sultan Abdul Kahar. Sejak inilah mulainya masa kesultanan di Jambi, yang berarti Islam telah benar-benar berwujud dalam bentuk "kekuasaan", Semua ini agaknya merupakan buah dari kenyataan di atas.

Masyarakat Jambi pada umumnya berpendapat bahwa Islam masuk dan di bawa oleh Ahmad Salim tahun 1460 Masehi. Sehingga tidak bisa dipungkiri bahwa kajian terhadap sejarah di daerah ini hanya kembali kepada rujukan yang telah ada saja. Untuk menentukan proses Islamisasi di Indonesia pada umumnya dan Jambi pada khususnya bukanlah suatu pekerjaan yang mudah, juga memakan waktu panjang, apalagi buktibukti arkeologis dan sumber-sumber asing kadang-kadang menunjukkan perbedaanperbedaan yang mencolok antara bukti adanya orang Islam dan proses pengembangan agama. Bukti-bukti sejarah yang menunjang pendapat di atas adalah:

1. Makam "Datuk Paduka Berhala" di pulau Berhala, suatu pulau kecil di gugusan daerah Tanjung Jabung Propinsi Jambi (sekarang Provinsi Kepulauan Riau).

2. Putri Selaras Pinang Masak dimakamkan di Desa "Pamunduran" sebelah Timur laut Jambi. ${ }^{14}$

Pada kedua makam tersebut pada waktu ditemukan tidak menjelaskan tahun. Demikian gambaran masuknya Islam di daerah Jambi. Akan tetapi, gambaran ini masih memerlukan penelitian lebih mendalam dan teliti sehingga pada masa tertentu nanti dapat ditemukan data-data yang dapat menjelaskan kekaburan-kekaburan sejarah masuknya Islam di daerah ini. Sebagian dari daerah Seberang Kota Jambi, mulai dari Kelurahan Olak Kemang sampai dengan Kelurahan Arab Melayu, terkenal dengan sebutan "Pacinan". Artinya tempat tinggal bagi para pedagang Cina. ${ }^{15}$ Sebutan ini diperkirakan telah ada sejak abad ke $18 \mathrm{M}$. Berdasarkan peninggalan benda sejarah yang ada di Museum Negeri Jambi, seperti bejana yang terbuat dari porselin Cina dari Dinasti Ming dan hiasan yang terdapat di atas rumah (bubungan) yang berarsitektur Cina, maka dapat disimpulkan betapa besar pengaruh Cina dalam kehidupan kebudayaan masyarakat.

Selain unsur Cina sebagai garis keturunan orang Seberang, juga ada unsur Arab. Unsur Arab yang datang setelah Ahmad Salim (awal abad ke 19 M.) adalah Sayyid Idrus Al Jufri, yang kemudian dikenal dengan sebutan atau bergelar Pangeran Wirokusumo. Dalam kedudukannya sebagai pangeran ia membantu sulthan dalam mengendalikan pemerintahan, lebih tinggi dari Datuk Sintai yang hanya berkedudukan sebagai Ngebi, (sekarang Lurah). Ngebi yang terakhir adalah Ngebi Somad. Keturunan tersebut sekarang tersebar di kelurahankelurahan sebagai berikut:

1. Garis keturunan Arab, banyak didapati di Kelurahan Arab Melayu dan Kelurahan Olak Kemang bagian hulu.

2. Garis keturunan Cina, banyak didapati di Kelurahan Olak Kemang bagian Hilir, Kelurahan Ulu Gedong, 


\section{Apdelmi \\ Islam dan Sejarahnya pada Masyarakat dambi Seberang}

Kelurahan Tengah, dan sebagian Kelurahan Jelmu. (Berdasarkan Hasil Wawan Cara juru kunci makam sayed Hussein Al Baraqbbah).

Masuknya Islam di daerah Seberang Kota ini bersamaan dengan pindahnya kerajaan Melayu dari daerah Tanjung Jabung ke pedalaman Jambi, yaitu "Tanah Pilih"16 pada masa pemerintahan "Rangkayo hitam." Tanah pilih sebagai pusat kerajaan hanya dipisahkan oleh sungai Batanghari dari daerah seberang Kota sehingga proses Islamisasi daerah seberang kota bersamaan pula waktunya dengan pemindahan kerajaan Melayu tersebut. Hanya saja tidak dapat diketahui secara pasti siapa yang pertama kali menyebarkan Islam di seberang Kota ini. Yang jelas pada masa itu orang Seberang telah mulai mengenal agama Islam karena di seberang Kota ada Bandar yang ramai dikunjungi oleh para pedagang asing termasuk yang beragama Islam. Hanya saja kalau ditanya tentang siapa, kapan, dan bagaimana cara pertama kali penyebaran Islam di seberang Kota Jambi belum diketahui secara pasti.

Sejauh penelitian penulis, di dalam masyarakat Seberang Kota berkembang suatu "cerita" bahwa Sayyid Husin Baragbah adalah seorang Ulama yang telah berjasa besar dalam memeperdalam pengertian dan penghayatan masyarakat terhadap Islam. Dan dari cerita-cerita yang masih hidup di kalangan keluarga keturunan "Baragbah" maupun dari orang-orang lain di daerah Seberang, tidak terdengar bahwa "Baragbah" adalah pembawa Islam yang pertama di daerah Seberang Kota Jambi. Tetapi kehadirannya membawa pengaruh besar bagi perkembangan agama Islam di daerahini.
Bisa jadi di daerah ini telah ada satu dua orang Islam yang memakai nama Arab sebelum dia, tetapi yang menonjol adalah Sayyid Husain Baragbah. ${ }^{17}$

Berikut ini adalah Makam sayyid hussain Al baraqbbah, beliau merupakan salah satu tokoh yang menyebar luaskan agama Islam di Jambi Seberang.

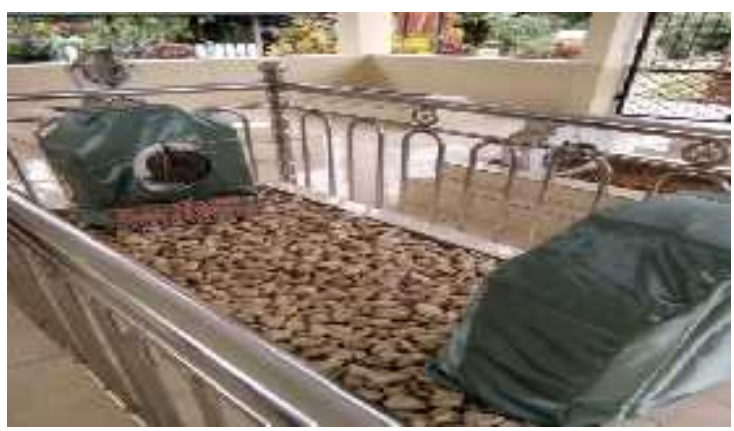

Gambar 3. Makam sayyid hussain Al baraqbbah Beliau wafat pada tahun $1173 \mathrm{H}$

Masuknya Islam di daerah Seberang Kota Jambi bersamaan dengan pindahnya kerajaan Melayu dari daerah Tanjung Jabung ke pedalaman Jambi, yaitu "Tanah Pilih" pada masa pemerintahan "Rangkayo hitam". Sedangkan sebagai pusat kerajaan berada di Tanah pilih yang terletak di Kota Jambi. Sedangkan orang yang pertama kali menyebarkan Islam di seluruhKota Jambi adalah Sayyid Husin bin Ahmad Baragbah, dan kehadirannya membawa pengaruh besar bagi perkembangan agama Islam di daerah ini.

\section{Endnote}

1Beberapa karya mencoba untuk
mencari titik temu beberapa teori
tentangsejarah awal penyebaran Islam di
Kepulauan Melayu-Nusantara, lihat Syed
Farid Alatas,"Notes on Various Theories
Regarding the Islamization of the Malay
Archipelago," in TheMuslim World, 75, (1985);


G.W.J. Drewes, "New Light on the Coming of Islam?" in Bijdragentot Taal-, Land- en Volkenkunde, 124, 1968, hlm. 433-459.

2Jan Vansina, Oral Tradition: A Study in Historical Methodology (Chicago: Aldine, 1965), hlm. 154-157

${ }^{3}$ Azyumardi Azra, Jaringan Ulama Timur Tengah dan Kepulauan Nusantara AbadXVII dan XVIII: Melacak Akar-Akar Pembaharuan Pemikiran Islam di Indonesia(Bandung:Mizan, 1994), hlm. 44.

${ }^{4}$ Sebenarnya, kapal-kapal perdagangan orang-orang dari Timur Tengah,termasuk Mesir, telah berlayar ke wilayah Nusantara jauh sebelum Nabi Muhammadmenyebarkan Islam di Makkah dan Madinah pada abad ke7. Lihat Jane Drakard, "AnIndian Ocean Port: Sources from the Earlier History of Barus," in Bijdragen tot Taal-LandenVolkenkunde, 1989, hlm. 37-38; Abdul Hadi WM., "Geografi dan Pelayaran Orang-orangArab,"Surat Kabar Harian Pelita, 19 Mei 1991, 4.

${ }^{5}$ A. H. Hill (penyt.), “Hikayat Raja-raja Pasai", JMBRAS, vol. 33, 1960.

${ }_{6}^{6}$. H. Djajadiningrat, Kesultanan Aceh, (Banda Aceh: P \& K, 1982), hlm. 7.

${ }^{7}$ C. C. Brown, Sejarah Melayu or Malay Annal (Kuala Lumpur: University ofMalaya Press, 1970), hlm. 43-44.

sSlametmuljana, Runtuhnya Kerajaan Hindu Jawa dan Timbulnya Negara-Negara Islam di Nusantara, hlm 129

${ }^{9}$ Marnawati djoened Poesponegoro, Sejarah Nasional Indonesia III, Zaman Pertumbuhan dan perkembangan Kerajaan Islam di Indonesia, hlm 40

${ }^{10}$ Elsbet lochers cholten, Sumatran sultanate and colonial state : Jambi and the rise of dutch Imperialism 1830-1907, translated from the ducth by Beverley Jackson, (USA : Conell SEAP, 2004), hlm 38

${ }^{11}$ Pulau berhala merupakan bukti sejarah terjadinya islamisasi di daerah jambi. Namun daerah yang memiliki luas kira-kira $200 \mathrm{Ha}$ ini ditetapkan sebagai bagaian dari Provinsi Kepulauan Riau dengan keputusan Mahkamah Agung Nomor 49 p/ HUM/2011

${ }^{12} \mathrm{R}$ Abdullah, Kenang-kenangan Jambi Nan Bertuah. Jambi. 1970. hlm.7

${ }^{13} \mathrm{R}$ Zainuddin, Sejarah Pendidikan di Daerah Jambi, Jambi, Pusat Peneliten Sejarah dan Budaya, Jambi, 1980, hlm. 10
${ }^{14}$ R.Zainuddin, Sejarah Pendidikan di Daerah Jambi, Jambi, Pusat Penelitian Sejarah dan Budaya, Jambi, 1980, hlm. 9

${ }^{15}$ Departemen Pendidikan Nasional, Sejarah Pendidikan Daerah Jambi. hlm, 15

${ }^{16}$ Lihat, M. Nazir, Mengenal candi-candi Muara Jambi, Jambi, (t,th), hlm. 5-8

${ }^{17}$ Menurut keterangan dari beberapa orang tokoh masyarakat, dan dari keturunan mereka (Sayyid Husain Baragbah) bahwa nama besar dan pengaruh yang begitu meluas di kalangan "orang Jambi" disebabkan oleh beberapa faktor: 1. Alim dan keluasan ilmu agamanya, sehingga ia menjadi panutan masyarakat dalam hal agama. 2. la berhasil mendekati dan membina hubungan baik dengan pihak Keraton (Sulthan Sri Anggo Logo). Hal ini dapat ditarik kesimpulan dari kasus perkawinannya dengan Rosi binti Sintai yang kemudian dikenal dengan sebutan $\mathrm{Nyi}$ Resi, atas anjuran dan campur tangan Sultan Sri Anggo Logo. 3. Sultan memberinya tanah yang luas, dan pengakuan sebagai keluarga. Bpk Taqiq Bin Ahmad Al Muqdhad, wawancara 8 maret 2017

\section{REFERENSI}

A. Mukty Nasruddin, "Jambi Dalam Sejarah Nusantara 692-1949," Stensilan,tidak diterbitkan

Abu Bakar, Usman, "Pendidikan Islam di Jambi: Corak Madrasah dari Kebudayaan Masyarakat Seberang Kota", Disertasi (S. 3) pada Fakultas Pasca-Sarjana IAIN (kini UIN) Syarif Hidayatullah Jakarta, 1992

Anonim, Sejarah Pendidikan Daerah Jambi, (Departemen Pendidikan dan Kebudayaan)

Aulia Tasman, Ph.D, Menelusuri Jejak Kerajaan Melayu Jambi Dan Perkembangannya Indonesia dalam arus sejarah, kedatangan dan peradaban islam, pt ichtiar bvaru van hoeve.

R. Abdullah, R., Kenang-Kenangan Jambi Nan-Betuah (Jambi, 1970)

Van Bruinessen, Martin, Kitab Kuning, Pesantrean dan Tarekat, (Bandung: Mizan, 1996)

Freitag, U., dan W. G. Clarence-Smith, Hadrami Traders, Scholars, and Statemen in the Indian Ocean, 1750s-1960s (Leiden: E. J. Brill, 1997)

Hazinah Mubarokah, Siti, "The Relationship Between Muslim's Woman Access to Formal Education and their Role Alteration in Public Sphere in Seberang Kota Jambi," Thesis S.2 